\title{
Detection of tick-borne pathogens in questing Ixodes ricinus in the French Pyrenees and first identification of Rickettsia monacensis in France
}

Toufic Akl ${ }^{1}$, Gilles Bourgoin ${ }^{2,3}$, Marie-Line Souq ${ }^{2}$, Joël Appolinaire ${ }^{4}$, Marie-Thérèse Poirel ${ }^{2,3}$, Philippe Gibert ${ }^{4}$, Georges Abi Rizk ${ }^{1}$, Mathieu Garel ${ }^{4}$, and Lionel Zenner, ${ }^{2,3}$ * $^{*}$

1 Université Libanaise, Faculté d'Agronomie et de Médecine Vétérinaire, Département de Médecine Vétérinaire, Beyrouth, Liban

2 Université de Lyon, VetAgro Sup - Campus Vétérinaire de Lyon, Laboratoire de Parasitologie Vétérinaire, 1 avenue Bourgelat, BP 83, 69280 Marcy l'Etoile, France

3 Université de Lyon, Université Lyon 1, CNRS, UMR 5558, Laboratoire de Biométrie et Biologie Évolutive, 69622 Villeurbanne, France

4 Office National de la Chasse et de la Faune Sauvage, Unité Ongulés Sauvages, 5 allée de Bethléem, 9 Z.I. Mayencin, 38610 Gières, France

Received 17 October 2018, Accepted 15 March 2019, Published online 3 April 2019

\begin{abstract}
Ticks are important vectors of several human and animal pathogens. In this study, we estimated the prevalence of important tick-borne infections in questing ticks from an area in Southwestern France (Hautes-Pyrénées) inhabited by Pyrenean chamois (Rupicapra pyrenaica pyrenaica) experiencing high tick burden. We examined adult and nymph ticks collected by the flag dragging method from 8 to 15 sites in the Pic de Bazès during the years 2009 , 2011, 2013 and 2015. PCR assays were conducted on selected ticks for the detection of Borrelia burgdorferi s.l., Babesia spp., Rickettsia spp., spotted fever group (SFG) Rickettsia and Anaplasma phagocytophilum. Randomly selected positive samples were submitted for sequence analysis. A total of 1971 questing ticks were collected including 95 males, 101 females and 1775 nymphs. All collected ticks were identified as Ixodes ricinus. Among them, 696 ticks were selected for pathogen detection and overall prevalence was $8.4 \%$ for B. burgdorferi s.1.; 0.4\% for Babesia spp.; $6.1 \%$ for A. phagocytophilum; $17.6 \%$ for Rickettsia spp.; and $8.1 \%$ for SFG Rickettsia. Among the sequenced pathogens, we detected in this population of ticks the presence of Babesia sp. EU1 and Rickettsia helvetica, as well as Rickettsia monacensis for the first time in France. The detection of these pathogens in the Pic de Bazès highlights the potential infection risks for visitors to this area and the Pyrenean chamois population.
\end{abstract}

Key words: Ixodes ricinus, Tick-borne infections, Public health, Pyrenean chamois, Rickettsia monacensis.

Résumé - Détection d'agents pathogènes présents chez les tiques errantes, Ixodes ricinus, dans les Pyrénées françaises et première identification de Rickettsia monacensis en France. Les tiques sont des vecteurs importants de plusieurs maladies animales et humaines. Dans cette étude, nous avons estimé la prévalence de maladies vectorisées chez les tiques errantes dans une région du sud-ouest de la France (Hautes-Pyrénées) occupée par des chamois des Pyrénées (Rupicapra pyrenaica pyrenaica) fortement infestés par les tiques. Nous avons utilisé des tiques adultes et des larves collectées par la technique du drapeau sur 8-15 sites du Pic de Bazès au cours des années 2009, 2011, 2013 et 2015. Des analyses PCR ont été menées sur des tiques sélectionnées pour la détection de Borrelia burgdorferi s.l., Babesia spp., Rickettsia spp., Rickettsia du groupe de la fièvre pourprée (GFP) et Anaplasma phagocytophilum. Des échantillons positifs sélectionnés au hasard ont été soumis à une analyse de séquences. Un total de 1971 tiques a été collecté dont 95 mâles, 101 femelles et 1775 larves. Toutes les tiques recueillies ont été identifiées comme étant Ixodes ricinus. Parmi celles-ci, 696 tiques ont été sélectionnées pour la détection des agents pathogènes et la prévalence globale était de $8,4 \%$ pour B. burgdorferi s.l., $0,4 \%$ pour Babesia spp., 6,1 \% pour A. phagocytophilum, 17,6 \% pour Rickettsia spp. et 8,1\% pour Rickettsia GFP. Parmi les agents pathogènes séquencés, nous avons détecté dans cette population de tiques la présence de Babesia sp. EU1, Rickettsia helvetica et, pour la première fois en France, Rickettsia monacensis. La détection de ces agents pathogènes dans le Pic de Bazès souligne les risques potentiels d'infection pour les visiteurs de cette région et pour la population de chamois des Pyrénées.

*Corresponding author: Iionel.zenner@vetagro-sup.fr

This is an Open Access article distributed under the terms of the Creative Commons Attribution License (http://creativecommons.org/licenses/by/4.0), which permits unrestricted use, distribution, and reproduction in any medium, provided the original work is properly cited. 


\section{Introduction}

Ticks are a major threat to human and animal health as they are one of the most important arthropod vectors of pathogens for both humans and wild and domestic animals. These pathogens include Borrelia burgdorferi s.l., Anaplasma phagocytophilum, Rickettsia spp., and Babesia spp. [19, 33, 47].

Climate change has a major impact on tick population distribution and dynamics, notably with the development of these arthropods in increasingly high densities at relatively high altitudes [12], as well as a shift in patterns of seasonal activity [14, 32]. This could widen the interface of these vectors to include hikers, domestic animals feeding on high altitude pastures, and wild animals inhabiting these high mountains, such as wild ungulates. These changes in tick dynamics are of serious concern as ticks are pathogen vectors and these changing dynamics could lead to increased transmission of tick-borne diseases [14].

The role of wild ungulates as reservoir hosts for Anaplasma phagocytophilum, spotted fever group (SFG) Rickettsia and Borrelia burgdorferi s.l. (sensu lato) is not completely understood [24], since these pathogens are not frequently associated with clinical disease. However, wild ungulates are known to play a role in the maintenance of these bacteria in nature [7, 31]. Clinical babesiosis has not often been described in wild ungulates, with the first case being detected in alpine chamois (Rupicapra rupicapra rupicapra) from Switzerland in 1964 [5]. This chamois showed extreme anemia, icterus, hepatomegaly and splenomegaly, and Babesia bovis was identified by microscopic examination of a blood smear. Since then, babesiosis was repeatedly detected in chamois [17, 18, 29]. In 2005, a chamois from the Swiss Alps with symptoms of piroplasmosis showed erythrocytic inclusions that were later confirmed by PCR and sequencing as Babesia capreoli, marking the first reported PCR identification of this parasite in clinically ill chamois [43].

Since 2002, we have observed relatively low kid spring survival $(0.52 \pm 0.04)$ with large year to year variations (from 0 to $0.75, \mathrm{CV}=42 \%$ ) in a population of Pyrenean chamois (Rupicapra pyrenaica pyrenaica) in the French Pyrenees (Pic de Bazès, Hautes-Pyrénées) [11, 41, 42]. Among the few corpses recovered, some had a high tick burden (>100 ticks), often associated with anemia, hemorrhage and splenomegaly, but the cause of death remained undetermined despite several laboratory investigations. Six apparently healthy individuals out of 10 trapped in 2008 had a positive PCR result for $B$. capreoli and B. venatorum (formerly known as Babesia sp. EU1), and 2 out of 5 (two dead and three shot) were positive by PCR for B. divergens in 2010 [13].

On the basis of these findings, a survey of the population of ticks in the Pic de Bazès was initiated in 2009. Based on the ticks collected in this survey, we investigated the critical pathogens harboured by this tick population.

\section{Materials and methods}

\section{Ticks collection and identification}

In this study, we used samples collected every other year from 2009 to 2015 (i.e., 2009, 2011, 2013, 2015) in the Pic de Bazès, in the foothills of the French Western Pyrenees $\left(43.00^{\circ} \mathrm{N}, 0.23^{\circ} \mathrm{W}\right)$, in the department of Hautes-Pyrénées in southwestern France.

The study area encompasses 400 ha between 1000 and $1800 \mathrm{~m}$ a.s.l., is mostly covered by alpine grass (Festuca eskia), rocks and forest (beech Fagus sylvatica and firs Abies sp.), and is inhabited by a population of 100-130 Pyrenean chamois [22]. During the study period, the average $( \pm S D)$ annual minimum and maximum daily temperatures were $5.8 \pm 5.7^{\circ} \mathrm{C}$ and $15.1 \pm 7.3{ }^{\circ} \mathrm{C}$, respectively (at $910 \mathrm{~m}$ a.s.l.). Total annual precipitations reached $1297 \pm 271 \mathrm{~mm}$.

Ticks were collected from 15 different sites in the study area until June 2013 and from the eight most infested sites afterwards. Ticks were collected by dragging a white flag of $1 \mathrm{~m}^{2}$ on vegetation along a $30 \mathrm{~m}$ line in each site. Sampling was repeated each month, from spring to fall. Collected ticks were placed in glass tubes with $70 \%$ ethanol or with a small piece of humid cotton. Due to the small size of larvae, they were not collected from the dragging flag.

Collected tick samples were transported to the laboratory and then identified using a binocular microscope. Species, stage and sex (for adults) were identified using morphological criteria following standard taxonomic keys [9, 37]. Ticks were stored individually in $1.5 \mathrm{~mL}$ plastic tubes with $70 \%$ ethanol and stored at $-20{ }^{\circ} \mathrm{C}$, or directly in a dry tube at $-80{ }^{\circ} \mathrm{C}$.

\section{DNA extraction}

As only a few adult specimens were collected per year, we extracted the DNA from all of them except in 2013, since they were abundant that year. We completed this dataset by randomly selecting adult ticks collected in 2013 (from the different sites and sampling periods), and nymphs (throughout the different years, sampling sites and periods). Prior to DNA extraction, ticks were individually washed twice for $10 \mathrm{~min}$ in $800 \mu \mathrm{L}$ of $70 \%$ ethanol then in sterile phosphate buffered saline (PBS), after which ticks were transferred into new $1.5 \mathrm{~mL}$ tubes and washed a final time with PBS. The tubes were vigorously vortexed after each bath and finally, PBS was removed to allow ticks to dry. Each tick was incised into small pieces while in the tube with a disposable no. 11 scalpel blade. DNA was then extracted from each tick using NucleoSpin ${ }^{\circledR}$ Tissue (Macherey-Nagel, Düren, Germany) for adults, and Nucleo Spin $^{\circledR}$ Tissue XS (Macherey-Nagel, Düren, Germany) for nymphs. At the final extraction step, DNA was eluted in $100 \mu \mathrm{L}$ of kit solution for adult ticks, and in $40 \mu \mathrm{L}$ for nymphs. Extracted DNA was stored at $-20{ }^{\circ} \mathrm{C}$ prior to molecular analyses.

\section{Molecular analyses}

The quality of the extracted DNA was verified by PCR amplification of a $320 \mathrm{bp}$ region of the mitochondrial $16 \mathrm{~S}$ rDNA specific to ticks using the primers TQ $16 \mathrm{~S}+1 \mathrm{~F}$ and TQ $16 \mathrm{~S}-2 \mathrm{R}$, as described in Table 1 [2]. A positive control consisting of Ixodes ricinus DNA and a negative control consisting of PCR product mix with no DNA were included. PCR products were then stained with bromophenol blue and examined 
Table 1. Primers used in the PCR assays conducted in this study with their respective references.

\begin{tabular}{|c|c|c|c|c|}
\hline Organism & Targeted gene (product size) & $\begin{array}{l}\text { Name and primer } \\
\text { sequences }\left(5^{\prime}-3^{\prime}\right)\end{array}$ & PCR conditions & Ref. \\
\hline Tick & Mitochondrial 16S rDNA (320 bp) & $\begin{array}{l}\text { TQ 16S+1F: } \\
\text { 5'-CTGCTCAATGATTTTTTA } \\
\text { AATTGCTGTGG-3' } \\
\text { TQ 16-2R: } \\
\text { 5'-ACGCTGTTATCC } \\
\text { CTAGAG-3' }\end{array}$ & $\begin{array}{l}\text { Denaturation } \\
94{ }^{\circ} \mathrm{C} 5 \mathrm{~min} \\
\text { Hybridization } \\
10 \text { cycles: } 92{ }^{\circ} \mathrm{C} 1 \mathrm{~min} ; \\
48{ }^{\circ} \mathrm{C} 1 \mathrm{~min} ; 72{ }^{\circ} \mathrm{C} 1 \mathrm{~min} 30 \mathrm{~s} \\
32 \text { cycles: } 92{ }^{\circ} \mathrm{C} 1 \mathrm{~min} ; \\
54{ }^{\circ} \mathrm{C} 1 \mathrm{~min} ; 72{ }^{\circ} \mathrm{C} 1 \mathrm{~min} 30 \mathrm{~s} \\
\text { Extension } \\
72{ }^{\circ} \mathrm{C} 5 \text { min }\end{array}$ & {$[2]$} \\
\hline Anaplasmataceae & 16S rRNA (345 bp) & $\begin{array}{l}\text { EHR 16SD: } \\
\text { 5'-GGTACCYACAGAA } \\
\text { GAAGTCC-3' } \\
\text { EHR 16SR: } \\
\text { 5'-TAGCACTCAT } \\
\text { CGTTTACAGC-3' }\end{array}$ & $\begin{array}{l}\text { Denaturation } \\
94{ }^{\circ} \mathrm{C} 5 \mathrm{~min} \\
\text { Hybridization } \\
34 \text { cycles: } 94{ }^{\circ} \mathrm{C} 40 \mathrm{~s} \text {; } \\
50{ }^{\circ} \mathrm{C} 40 \mathrm{~s} ; 72{ }^{\circ} \mathrm{C} 1 \mathrm{~min} \\
\text { Extension } \\
72{ }^{\circ} \mathrm{C} 10 \mathrm{~min}\end{array}$ & [36] \\
\hline \multirow[t]{2}{*}{$\begin{array}{l}\text { Anaplasma } \\
\quad \text { phagocytophilum }\end{array}$} & 16S rDNA (932 bp) & $\begin{array}{l}\text { ge3a: } \\
\text { 5'-CACATGCAAGTCGA } \\
\text { ACGGATTATTC-3' } \\
\text { ge10r: } \\
\text { 5'-TTCCGTTAAGAAGG } \\
\text { ATCTAATCTCC-3' }\end{array}$ & $\begin{array}{l}\text { Denaturation } \\
95^{\circ} \mathrm{C} 5 \mathrm{~min} \\
\text { Hybridization } \\
40 \text { cycles: } 94{ }^{\circ} \mathrm{C} 30 \mathrm{~s} \text {; } \\
55^{\circ} \mathrm{C} 30 \mathrm{~s} ; 72^{\circ} \mathrm{C} 1 \mathrm{~min} \\
\text { Extension } \\
72{ }^{\circ} \mathrm{C} 5 \mathrm{~min}\end{array}$ & [28] \\
\hline & 16S rDNA (546 bp) & $\begin{array}{l}\text { ge9f: } \\
\text { 5'-AACGGATTATTCTTT } \\
\text { ATAGCTTGCT-3' } \\
\text { ge2r: } \\
\text { 5'-GGCAGTATTAAAAGC } \\
\text { AGCTCCAGG-3' }\end{array}$ & $\begin{array}{l}\text { Denaturation } \\
95^{\circ} \mathrm{C} 5 \mathrm{~min} \\
\text { Hybridization } \\
30 \text { cycles: } 94{ }^{\circ} \mathrm{C} 30 \mathrm{~s} \text {; } \\
55^{\circ} \mathrm{C} 30 \mathrm{~s} ; 72{ }^{\circ} \mathrm{C} 1 \mathrm{~min} \\
\text { Extension } \\
72{ }^{\circ} \mathrm{C} 5 \mathrm{~min}\end{array}$ & \\
\hline $\begin{array}{l}\text { Borrelia } \\
\quad \text { burgdorferi s.l. }\end{array}$ & 16S rRNA (357 bp) & $\begin{array}{l}\text { 16S LDF: } \\
\text { 5'-ATGCACACTTGGT } \\
\text { GTTAACTA-3' } \\
\text { 16S LDR: } \\
\text { 5'-GACTTATCACCGG } \\
\text { CAGTCTTA-3' }\end{array}$ & $\begin{array}{l}\text { Denaturation } \\
95{ }^{\circ} \mathrm{C} 5 \mathrm{~min} \\
\text { Hybridization } \\
35 \text { cycles: } 95{ }^{\circ} \mathrm{C} 1 \mathrm{~min} \text {; } \\
53{ }^{\circ} \mathrm{C} 1 \mathrm{~min} ; 72{ }^{\circ} \mathrm{C} 1 \mathrm{~min} \\
\text { Extension } \\
\quad 72^{\circ} \mathrm{C} 10 \mathrm{~min}\end{array}$ & [27] \\
\hline $\begin{array}{l}\text { Babesia/Theileria } \\
\text { spp. }\end{array}$ & 18S rRNA (359 bp) & $\begin{array}{l}\text { BAB GF2: } \\
\text { 5'-GYYTTGTAATTG } \\
\text { GAATGATGG-3' } \\
\text { BAB GR2: } \\
\text { 5'-CCAAAGACTTT } \\
\text { GATTTCTCTC-3' }\end{array}$ & $\begin{array}{l}\text { Denaturation } \\
94{ }^{\circ} \mathrm{C} 5 \mathrm{~min} \\
\text { Hybridization } \\
35 \text { cycles: } 94{ }^{\circ} \mathrm{C} 1 \mathrm{~min} \text {; } \\
60{ }^{\circ} \mathrm{C} 1 \mathrm{~min} ; 72{ }^{\circ} \mathrm{C} 1 \mathrm{~min} \\
\text { Extension } \\
\quad 72{ }^{\circ} \mathrm{C} 10 \mathrm{~min}\end{array}$ & {$[4]$} \\
\hline Rickettsia spp. & gltA (citrate synthase) (381 bp) & $\begin{array}{l}\text { RpCS.877p: } \\
\text { 5'-GGGGGCCTGCTC } \\
\text { ACGGCGG-3' } \\
\text { RpCS.1258n: } \\
\text { 5'-ATTGCAAAAAGT } \\
\text { ACAGTGAACA-3' }\end{array}$ & $\begin{array}{l}\text { Denaturation } \\
95^{\circ} \mathrm{C} 5 \mathrm{~min} \\
\text { Hybridization } \\
6 \text { cycles: } 94{ }^{\circ} \mathrm{C} 1 \mathrm{~min} ; \\
60{ }^{\circ} \mathrm{C} 1 \mathrm{~min} ; 72{ }^{\circ} \mathrm{C} 1 \mathrm{~min}\end{array}$ & [39] \\
\hline
\end{tabular}


Table 1. (Continued)

\begin{tabular}{|c|c|c|c|c|}
\hline Organism & Targeted gene (product size) & $\begin{array}{l}\text { Name and primer } \\
\text { sequences }\left(5^{\prime}-3^{\prime}\right)\end{array}$ & PCR conditions & Ref. \\
\hline & & & $\begin{array}{l}30 \text { cycles: } 94{ }^{\circ} \mathrm{C} 1 \mathrm{~min} \text {; } \\
53{ }^{\circ} \mathrm{C} 1 \mathrm{~min} ; 72{ }^{\circ} \mathrm{C} 1 \mathrm{~min} \\
\text { Extension } \\
\quad 72{ }^{\circ} \mathrm{C} 10 \mathrm{~min}\end{array}$ & \\
\hline \multirow[t]{2}{*}{ SFG Rickettsia } & ompA (532 bp) & $\begin{array}{l}\text { Rr190.70p: } \\
\text { 5'-ATGGCGAATATT } \\
\text { TCTCCAAAA-3' }\end{array}$ & $\begin{array}{l}\text { Denaturation } \\
95^{\circ} \mathrm{C} 5 \mathrm{~min}\end{array}$ & [39] \\
\hline & & $\begin{array}{l}\text { Rr190.602n: } \\
\text { 5'-AGTGCAGCATTC } \\
\text { GCTCCCCCT-3' }\end{array}$ & $\begin{array}{l}\text { Hybridization } \\
\text { Six cycles : } 94{ }^{\circ} \mathrm{C} 1 \mathrm{~min} \text {; } \\
60{ }^{\circ} \mathrm{C} 1 \mathrm{~min} ; 72{ }^{\circ} \mathrm{C} 1 \mathrm{~min} \\
30 \text { cycles : } 94{ }^{\circ} \mathrm{C} 1 \mathrm{~min} \text {; } \\
53{ }^{\circ} \mathrm{C} 1 \mathrm{~min} ; 72{ }^{\circ} \mathrm{C} 1 \mathrm{~min} \\
\text { Extension } \\
\quad 72{ }^{\circ} \mathrm{C} 10 \mathrm{~min}\end{array}$ & \\
\hline
\end{tabular}

by gel electrophoresis (1.5\% agarose gel, Standard Agarose, Eurobio, France), and detected using ultraviolet light (Kodak EDAS 290, New York, USA).

All positive DNA samples were screened for the presence of DNA of Borrelia burgdorferi s.l., Anaplasmataceae, Babesial Theileria spp. and Rickettsia spp. Independent PCR assays were conducted using the primers and conditions presented in Table 1. Nested PCR assay using ge3a/ge10r as the first primer couple and ge9f/ge $2 \mathrm{r}$ as the second, amplifying a part of the 16S rDNA specific to Anaplasma phagocytophilum was conducted only on positive samples to Anaplasmataceae, except for the samples collected in 2009, which were previously tested directly with the A. phagocytophilum nested PCR. Similarly, for SFG Rickettsia, only samples that were positive for Rickettsia spp. were tested. PCR assays were further analyzed using the primer couple Rr190.70p/Rr190.602n, amplifying the ompA gene specific for SFG Rickettsia. Positive and negative controls were included in each run. All amplified products were examined by gel electrophoresis as described above.

\section{Sequence analysis}

A representative number of positive samples for each tested pathogen showing clear positive strands on gel electrophoresis were randomly selected for sequence analysis. Samples were sent to Biofidal Laboratory (Villeurbanne, France) for sequencing in both directions using the same primers as the ones employed in the PCR assays. We used CLC Main Workbench 8 (Qiagen, Hilden, Germany) to analyze the quality of the sequences and create consensus sequences. This consensus was compared with sequences available from the GenBank ${ }^{\circledR}$ database with the BLAST tool of the CLC Main Workbench.

\section{Statistical analyses}

Fisher's exact tests were used to study the effects of tick stage (i.e., adult or nymph) and year of collection on the prevalence of pathogens. Statistical analyses were conducted with the software STATISTICA $10^{\circledR}$ (Stat Soft Inc., 2011). A significance threshold level of 0.05 was used.

\section{Results \\ Ticks collected}

A total of 1971 questing ticks were collected during the study period including 95 males, 101 females and 1775 nymphs. All ticks were identified as Ixodes ricinus.

DNA extraction and PCR assays for the detection of vectorborne pathogens were conducted on 79 males, 86 females and 531 nymphs (i.e., $83.2 \%, 85.1 \%$ and $29.9 \%$ of the total number of collected males, females and nymphs, respectively) sampled from each site and year (see Table 2 for details on the number of ticks per year).

\section{Detection of Borrelia burgdorferi s.I.}

DNA of Borrelia burgdorferi s.l. was found in $8.4 \%$ of tested ticks (59/696) with significant strong annual (0-21.3\%) and site (0-29.4\%) variations (Table 2). Prevalence of infection in questing ticks in 2013 was $21.3 \%$, making it significantly higher than all the other years $(p<0.05)$. Questing nymphs collected over the four years were found to have a significantly higher infection rate $(p<0.05)$ than adult ticks $(9.7 \%$ vs. $4.2 \%$; $p<0.05$ ), except in 2011 (0\% vs. 10.7\%).

Fifteen of the 59 Borrelia burgdorferi s.l. positive samples were further analyzed by sequencing. The five samples from 2009 that were sequenced produced highly similar consensus sequences of 351 nucleotides that revealed $100 \%$ similarity with sequences of the $16 \mathrm{~S}$ gene of Borrelia afzelii isolated from ticks and humans (GenBank accession numbers EF541175 and CP002933, respectively). The remaining samples (i.e., 5 from 2011 and 5 from 2013; 258-354 bp) showed 99-100\% similarity with sequences of different genospecies of $B$. burgdorferi $\mathrm{s}$. 1. complex, such as cultured B. burgdorferi s.s. and B. garinii isolated from Ixodes spp. ticks (GenBank accession numbers CP031412 and KY346890, respectively).

\section{Detection of Babesia/Theileria spp.}

Molecular analyses revealed the presence of Babesial Theileria spp. DNA in three of the 696 tested samples 
Table 2. The results of PCR assays for the different tested pathogens with the corresponding percentages.

\begin{tabular}{|c|c|c|c|c|c|c|c|c|c|c|c|c|}
\hline \multirow[t]{2}{*}{ Year } & \multicolumn{2}{|c|}{$\begin{array}{c}\text { Borrelia } \\
\text { burgdorferi s.l. }\end{array}$} & \multicolumn{2}{|c|}{$\begin{array}{l}\text { Babesia/Theileria } \\
\text { spp. }\end{array}$} & \multicolumn{2}{|c|}{ Rickettsia spp. } & \multicolumn{2}{|c|}{ SFG Rickettsia } & \multicolumn{2}{|c|}{ Anaplasmataceae } & \multicolumn{2}{|c|}{ A. phagocytophilum } \\
\hline & positive/tested & $\%$ & positive/tested & $\%$ & positive/tested & $\%$ & positive/tested & $\%$ & positive/tested & $\%$ & positive/tested & $\%$ \\
\hline \multicolumn{13}{|l|}{2009} \\
\hline Male & $0 / 13$ & 0 & $0 / 13$ & 0 & $0 / 13$ & 0 & - & - & - & - & $0 / 13$ & 0 \\
\hline Female & $0 / 9$ & 0 & $0 / 9$ & 0 & $1 / 9$ & 11.1 & $0 / 1$ & 0 & - & - & $1 / 9$ & 11.1 \\
\hline Nymph & $5 / 133$ & 3.7 & $2 / 133$ & 1.5 & $0 / 133$ & 0 & - & - & - & - & $6 / 133$ & 5 \\
\hline Total & $5 / 164$ & 3.0 & $2 / 164$ & 1.2 & $1 / 164$ & 0.6 & $0 / 1$ & 0 & - & - & $8 / 164$ & 4.8 \\
\hline \multicolumn{13}{|l|}{2011} \\
\hline Male & $2 / 21$ & 9.5 & $0 / 21$ & 0 & $11 / 21$ & 52.3 & $1 / 11$ & 9.0 & $1 / 21$ & 4.7 & $0 / 1$ & 0 \\
\hline Female & $3 / 26$ & 11.5 & $0 / 26$ & 0 & $14 / 26$ & 53.8 & $2 / 14$ & 14.2 & $25 / 26$ & 96.1 & $0 / 25$ & 0 \\
\hline Nymph & $0 / 137$ & 0 & $0 / 137$ & 0 & $46 / 137$ & 33.5 & $0 / 46$ & 0 & $15 / 137$ & 10.9 & $3 / 15$ & 20 \\
\hline Total & $5 / 184$ & 2.7 & $0 / 184$ & 0 & $71 / 184$ & 38.5 & $3 / 71$ & 4.2 & $41 / 184$ & 22.2 & $3 / 41$ & 7.3 \\
\hline \multicolumn{13}{|l|}{2013} \\
\hline Male & $2 / 31$ & 6.4 & $0 / 31$ & 0 & $8 / 31$ & 25.8 & $0 / 8$ & 0 & $2 / 31$ & 6.4 & $1 / 2$ & 50 \\
\hline Female & $0 / 29$ & 0 & $0 / 29$ & 0 & $4 / 29$ & 13.7 & $0 / 4$ & 0 & $7 / 29$ & 24.1 & $0 / 7$ & 0 \\
\hline Nymph & $47 / 170$ & 27.6 & $1 / 170$ & 0.5 & $27 / 170$ & 15.8 & $3 / 27$ & 11.1 & $37 / 170$ & 21.7 & $4 / 37$ & 11 \\
\hline Total & $49 / 230$ & 21.3 & $1 / 230$ & 0.4 & $39 / 230$ & 16.9 & $3 / 39$ & 7.6 & $46 / 230$ & 20.0 & $5 / 46$ & 10.8 \\
\hline \multicolumn{13}{|l|}{2015} \\
\hline Male & $0 / 14$ & 0 & $0 / 14$ & 0 & $1 / 14$ & 7.1 & $1 / 1$ & 100 & $1 / 14$ & 7.1 & $0 / 1$ & 0 \\
\hline Female & $0 / 22$ & 0 & $0 / 22$ & 0 & $9 / 22$ & 40.9 & $2 / 9$ & 22.2 & $18 / 22$ & 81.8 & $1 / 18$ & 5.5 \\
\hline Nymph & $0 / 91$ & 0 & $0 / 91$ & 0 & $2 / 91$ & 2.2 & $1 / 2$ & 50.0 & $1 / 91$ & 1.1 & $0 / 1$ & 0 \\
\hline Total & $0 / 127$ & 0 & $0 / 127$ & 0 & $12 / 127$ & 9.4 & $4 / 12$ & 33.3 & $20 / 127$ & 15.7 & $1 / 20$ & 5.0 \\
\hline Total & $59 / 696$ & 8.4 & $3 / 696$ & 0.4 & $123 / 696$ & 17.6 & $10 / 123$ & 8.1 & $107 / 541$ & 19.7 & $16 / 262$ & 6.1 \\
\hline
\end{tabular}

(prevalence of $0.4 \%$ ). Two of these positive samples were collected in 2009 and the third one was detected in a sample from 2013 (Table 2).

All three positive samples were submitted for sequence analysis. The two samples collected in 2009 showed the closest similarity (99.1\%) to a sequence of the $18 \mathrm{~S}$ gene of Babesia sp. EU1 isolated from roe deer in France (GenBank accession number HQ830266). The positive sample collected in 2013 (722 bp) showed $99.7 \%$ similarity to a sequence of Babesia sp. EU1 isolated from I. ricinus ticks in the Czech Republic (GenBank accession number KX857480).

\section{Detection of Rickettsia spp.}

The overall prevalence of Rickettsia spp. was found to be $17.6 \%$ (123/696), with statistically significant annual (0.6-38.5\%) and site (9.6-50\%) variations (Table 2). Adult ticks had a significantly higher infection prevalence than nymphs $(29.0 \%(48 / 165)$ vs. $14.1 \%(75 / 531) ; p<0.05)$.

An additional PCR assay was conducted on all positive samples with a probe amplifying the ompA gene specific to SFG Rickettsia which revealed 10 positive samples $(8.1 \%)$, with the highest prevalence in 2015 (4/10). Tick stage and site of collection showed no significant effect on prevalence.

Five of the 10 positive SFG Rickettsia samples were submitted for sequence analysis. The consensus sequences (510-530 bp) showed $100 \%$ similarity to the ompA gene sequence of $R$. monacensis isolated from I. ricinus larvae in Italy (GenBank accession number KY319223). Two samples positive with the gltA probe, but negative with ompA, were submitted for sequence analysis with the gltA primer.
Consensus sequences (384-385 bp) showed $100 \%$ similarity to $R$. helvetica isolated from $I$. ricinus ticks infesting dogs in central Italy (GenBank accession number KY231198).

\section{Detection of Anaplasmataceae and Anaplasma phagocytophilum}

PCR assay conducted for the detection of the DNA of Anaplasmataceae on samples collected in 2011, 2013 and 2015 revealed a prevalence of $19.7 \%$ (107/541; Table 2). A nested PCR that identifies Anaplasma phagocytophilum was conducted on all positive samples, in addition to all the samples collected in 2009. Overall prevalence of A. phagocytophilum was found to be $6.1 \%(16 / 262)$. No significant effect of tick stage and year of collection on the prevalence of A. phagocytophilum were detected.

Three positive samples from 2011 and one from 2015 out of the 15 positive $A$. phagocytophilum samples (4/15) were submitted for sequence analysis. The sample collected in 2015 (530 bp) and one of the samples from the year 2011 revealed $100 \%$ similarity with a sequence of the 16S RNA gene of A. phagocytophilum isolated from mouflon blood samples in the Czech Republic (GenBank accession number EU839851). The two remaining samples showed $100 \%$ similarity to A. phagocytophilum isolated from sika deer spleen samples in Germany (GenBank accession number KU705182).

\section{Co-infections}

A total of 71 co-infections were found between all the tested samples (10.2\%) (Table 3). Five among these co-infections were tri-infections by $B$. burgdorferi s.l with Rickettsia 
Table 3. The observed frequency of co-infections detected by PCR assays in I. ricinus ticks.

\begin{tabular}{lcccccc}
\hline & B. burgdorferi s.l. & Babesia spp. & Rickettsia spp. & SFG Rickettsia & Anaplasmataceae & A. phagocytophilum \\
\hline B. burgdorferi s.l. & - & - & - & - & - & - \\
Babesia spp. & 0 & - & - & - & - & - \\
Rickettsia spp. & $\mathbf{1 7}$ & 1 & - & - & - & - \\
SFG Rickettsia & 1 & 0 & - & - & - & - \\
Anaplasmataceae & 14 & 0 & $\mathbf{3 8}$ & 0 & - & - \\
A. phagocytophilum & 2 & 0 & 2 & 0 & - \\
\hline
\end{tabular}

spp. and Anaplasmataceae, and one was a tri-infection by B. burgdorferi s.l. and SFG Rickettsia and Anaplasmataceae.

\section{Discussion}

A survey for the detection of tick-borne pathogens circulating in the Pic de Bazès was conducted, following the observation of relatively low and variable kid spring survival in the local population of Pyrenean chamois [42], high infestations by ticks on some animals, and the presence of three species of tick-borne Babesia [13]. In this study, B. burgdorferi s.l., Babesia spp., Rickettsia spp. and Anaplasma phagocytophilum were detected in I. ricinus ticks collected in 2009, 2011, 2013 and 2015.

All collected ticks were identified as I. ricinus, which is considered as one of the most commonly found tick species in Europe [6]. In this study, the overall number of adult ticks ( $n=196)$ was considerably lower than the number of nymphs collected ( $n=1775)$, as in many other studies using the similar dragging technique for collecting questing ticks [3, 38]. This confirms the low performance of this technique to collect adult ticks [38]. Tick abundance also varied greatly according to the year of collection which can be explained by yearly variations in environmental factors known to affect the abundance and activity of ticks, such as relative humidity, temperature, soil type, vegetation and animal density [21], and also by a lower number of sampling sites in 2015 compared to previous years (8 vs. 15$)$.

The overall prevalence of B. burgdorferi s.l. in our study was found to be close to that found in a similar study carried out in Italy (5.8\%) [38], but lower than that reported in Switzerland $(20-35 \%)$ [20]. In this study, except in 2011, the overall infection prevalence of nymphs appeared to be significantly higher than that of adults, while the opposite was expected. In fact, this spirochaete is known to be acquired by ticks via blood feeding and interstadial transmission, and therefore adults are expected to show a higher prevalence than nymphs as observed in I. ricinus in Switzerland [20]. However, such findings are not always consistent, since other similar studies found no significant difference in relevance to tick stage [30].

Sequence analysis of positive samples collected in 2011 and 2013 showed $99-100 \%$ identity to multiple species of the $B$. burgdorferi s.l complex, such as B. burgdorferi s.s. and $B$. garinii. As a consequence, sequencing of these samples does not allow the deduction of the identified pathogen species. On the other hand, positive samples collected in 2009 showed
$100 \%$ identity with B. afzelii. While B. afzelii and B. garinii are mainly associated with rodents and birds [26], they are both responsible for clinical disease in humans. In fact, in the administrative region of Occitanie, the incidence rate of human Lyme borreliosis was found to be between 20 and 59 per 100,000 inhabitants in a study conducted from 2009 to 2012 [46]. Therefore, the identification of pathogenic B. burgdorferi s.l. in ticks of the Pic de Bazès should raise awareness of the possibility of contracting Lyme borreliosis in this area [20].

In our study, Babesia spp. prevalence was $0.4 \%$ which is in accordance with similar studies carried in European countries such as Poland, Germany, Slovakia and Switzerland where infection rates were between 0.4 and $4.5 \%$ [16, 44]. In fact, I. ricinus carrier rates of Babesia spp. rarely exceed this range [30].

All three positive samples were sequenced and showed over 99\% similarity with Babesia sp. EU1, which is in accordance with its detection from six Pyrenean chamois of the Pic de Bazès in 2008 [13]. These animals were in apparent healthy condition but Babesia sp. EU1 is considered to be one of the Babesia species causing clinical disease in humans and also in chamois [13, 30]. However, in the latter report, B. capreoli and $B$. divergens were also detected [13], which was not the case in the current study. In another study conducted in Switzerland, Babesia sp. EU1 was identified in $64.3 \%$ of positive Babesia spp. samples while B. divergens was identified in $17.9 \%$ [25], which highlights the importance of Babesia sp. EU1 in relation to other Babesia species. Therefore, the absence of $B$. capreoli and $B$. divergens detection in this study could be simply explained by the low Babesia spp. prevalence. Nevertheless, these findings prove the circulation of Babesia spp. in ticks of the Pic de Bazès, which might influence the demography of the local population of Pyrenean chamois [13].

In the current study, overall Rickettsia spp. prevalence was $17.6 \%$ with the highest prevalence being found in 2011 (38.5\%) and the lowest in $2009(0.6 \%)$. A study on the detection of Rickettsia spp. in I. ricinus collected in 2007 from Pyrenean chamois in the same area as this study revealed a prevalence of $6 \%$ [6]. In Germany, the detection of Rickettsia spp. in questing I. ricinus also revealed a large variation between 2005 and 2015 with prevalence ranging from 26.2 to $50.8 \%$ [3].

We had significantly higher infection rates in adult ticks compared to nymphs, as previously observed [3]. However, the effect of tick stage on prevalence of Rickettsia spp. varies between studies with some revealing the absence of effect, which is often assumed to result from the dual interstadial and transovarian transmission of this pathogen [15]. 
SFG Rickettsia was detected in $8.1 \%$ of positive Rickettsia spp. samples. However, it is important to note that this is not the real SFG Rickettsia prevalence, since an additional PCR assay amplifying the ompB gene is necessary to confirm that negative samples are indeed non-SFG Rickettsia [10]. Therefore, Rickettsia spp. positive samples not exhibiting the ompA gene should not systematically be considered as symbiotic bacteria. This justifies the submission of such samples for sequence analyses.

Sequence analyses revealed $100 \%$ identity with $R$. helvetica and $R$. monacensis. The former is considered the predominant Rickettsia species in Germany, while the latter is associated with sporadic cases [3]. This is, to our knowledge, the first identification of $R$. monacensis in France. This bacterium has been detected in I. ricinus in different countries in Europe, with prevalence in ticks ranging from 1 to $57 \%$, depending of the studies. It has also been detected in lizard tissues, but more importantly, was identified as a human pathogen in two patients in Spain [35].

$R$. helvetica was similarly detected in ticks collected from Pyrenean chamois from the Pic de Bazès [6], with 98.9\% identity. In addition, our study has detected similarity with $R$. monacensis, an emerging human pathogen which was not found in the previous analyses of ticks from the Pic de Bazès [6].

A. phagocytophilum is an obligate intracellular bacterium of the Anaplasmataceae family, infecting neutrophils. In ruminants, A. phagocytophilum causes Tick-Borne Fever, a mild disease with non-specific signs (fever, lethargy and anorexia). This bacterium is maintained by animals recovering from clinical disease that become persistent carriers [8], while in wild ecosystems, it is maintained through enzootic cycles between ticks and wild and domestic animals (e.g., cervids, rodents, migratory birds, sheep) acting as reservoirs [34, 48].

A. phagocytophilum is mainly transmitted in Europe by I. ricinus ticks [23]. Prevalence of the pathogen in Europe ranges from 0.4 to $67 \%$, depending on the studied area. In fact, prevalence in questing I. ricinus ranged between 1.0 and $17.4 \%$ in Germany; 3.7 and $20.5 \%$ in Spain; and 1.5 and $24.4 \%$ in Italy [45]. In this study, A. phagocytophilum was detected in $6.1 \%$ of the tested I. ricinus. Studies conducted in different areas of France on questing ticks are in accordance with our results with prevalence not exceeding $10.7 \%$ [1, 15, 40]. Ticks tested in our study were collected from an area with vegetation mainly represented by pastures and shrubs, surrounded by woodland. Forest fragmentation is considered to favor the prevalence of $A$. phagocytophilum in woodland and pastures due to the abundance of rodents in this type of environment [15]. Therefore, the Pic de Bazès is potentially a favorable zone for the maintenance of this bacterium, which could be a threat to humans visiting the site.

The largest number of co-infections found in this study were between Anaplasmataceae and Rickettsia spp. $(n=38)$ and between Borrelia burgdorferi s.l. and Rickettsia spp. ( $n=17)$. While Rickettsia spp. detected in this study contains a large number of potentially pathogenic bacteria, Anaplasmataceae contain only a few, with the remainder being symbiotic bacteria. As a result, co-infections with Anaplasmataceae should be interpreted carefully in order to avoid overestimating the importance of these bacteria as pathogens. Since
B. burgdorferi s.l., Rickettsia spp. and Anaplasmataceae share similar reservoir hosts (i.e., rodents) as well as vector species (i.e., I. ricinus), significant rates of co-infection are to be expected. In fact, other studies have previously reported A. phagocytophilum and Rickettsia spp. co-infections [3].

\section{Conclusion}

Following the detection of Babesia sp. EU1 in Pyrenean chamois of the Pic de Bazès, we also detected the same pathogen in questing ticks in our study. In addition, we detected B. burgdorferi s.l., Babesia spp., A. phagocytophilum and SFG Rickettsia, with sequence analysis revealing, to our knowledge, the presence of Rickettsia monacensis for the first time in France. Furthermore, the zoonotic nature of these tick-borne infections indicates the need to raise awareness of the risk of contracting these pathogens for humans visiting the area.

Acknowledgements. We are grateful to Kevin Foulché for his strong involvement in the Pyrenean studies, and to Julien Garnier and the numerous trainees for their help in the field. Many thanks also to Julie Cat for managing ticks in the laboratory.

\section{Conflict of interest}

The authors declare that they have no conflict of interest.

\section{References}

1. Beytout J, George J, Malaval J, Garnier M, Beytout M, Baranton G, Ferquel E, Postic D. 2007. Lyme borreliosis incidence in two French departments: correlation with infection of Ixodes ricinus ticks by Borrelia burgdorferi sensu lato. Vector Borne and Zoonotic Diseases, 4, 507-517.

2. Black WC, Piesman J. 1994. Phylogeny of hard- and sof-tick taxa (Acari: Ixodida) based on mitochondrial 16S rDNA sequences. Proceedings of the National Academy of Sciences of the USA, 91, 10034-10038.

3. Blazejak K, Janecek E, Strube C. 2017. A 10-year surveillance of Rickettsiales (Rickettsia spp. and Anaplasma phagocytophilum) in the city of Hanover, Germany, reveals Rickettsia spp. as emerging pathogens in ticks. Parasites \& Vectors, 10, 588.

4. Bonnet S, Jouglin M, Malandrin L, Becker C, Agoulon A, L'Hostis M, Chauvin A. 2007. Transstadial and transovarial persistence of Babesia divergens DNA in Ixodes ricinus ticks fed on infected blood in a new skin-feeding technique. Parasitology, 134, 197-207.

5. Bouvier G. 1965. Observations on the diseases of game and wild animals in 1963 and 1964. Schweizer Archiv für Tierheilkunde, 107, 634-647.

6. Davoust B, Socolovschi C, Revelli P, Gibert P, Marié J-L, Raoult D, Parola P. 2012. Detection of Rickettsia helvetica in Ixodes ricinus ticks collected from Pyrenean chamois in France. Ticks and Tick-Borne Diseases, 3, 386-387.

7. de la Fuente J, Estrada-Pena A, Venzal J, Kocan K, Sonenshine D. 2008. Overview: ticks as vectors of pathogens that cause disease in humans and animals. Frontiers in Bioscience, 13, 6938-6946.

8. Ebani V, Cerri D, Fratini F, Ampola M, Andreani E. 2008. Seroprevalence of Anaplasma phagocytophilum in domestic and wild animals from central Italy. New Microbiologica, 31, 371-375. 
9. Estrada Pena A, Bouattour A, Camicas J-L, Walker AR. 2004. Ticks of domestic animals in the mediterranean region: a guide to identification of species. Houten, The Netherlands: University of Zaragoza.

10. Fournier P-E, Dumler JS, Greub G, Zhang J, Wu Y, Raoult D. 2003. Gene sequence-based criteria for identification of new Rickettsia isolates and description of Rickettsia heilongjiangensis sp. nov. Journal of Clinical Microbiology, 41, 5456-5465.

11. Gaillard JM, Festa-Bianchet M, Yoccoz NG, Loison A, Toïgo C. 2000. Temporal variation in fitness components and population dynamics of large herbivores. Annual Review of Ecology and Systematics, 31, 367-393.

12. Gern L, Cadenas F, Burri C. 2008. Influence of some climatic factors on Ixodes ricinus ticks studied along altitudinal gardients in two geographic regions in Switzerland. International Journal of Medical Microbiology, 298, 55-59.

13. Gibert P. 2017. Surveillance sanitaire de la faune sauvage. Rueil Malmaison: Éditions du Point vétérinaire.

14. Gray J, Dautel H, Estrada-Pena A, Kahl O, Lindgren E. 2009. Effects of climate change on ticks and tick-borne diseases in Europe. Interdisciplinary Perspective on Infectious Diseases, 2009, 593232.

15. Halos L, Bord S, Cotté V, Gasqui P, Abrial D, Barnouin J, Boulouis HJ, Vayssier-Taussat M, Vourc'h G. 2010. Ecological factors characterizing the prevalence of bacterial tick-borne pathogens in Ixodes ricinus ticks in pastures and woodlands. Applied and Environmental Microbiology, 13, 4413-4420.

16. Hamsikova Z, Kazimirova M, Harustiakova D, Mahrikova L, Slovak M, Berthova L, Kocianova E, Schnittger L. 2016. Babesia spp. in ticks and wildlife in different habitat types of Slovakia. Parasites \& Vectors, 9, 292.

17. Hoby S, Robert N, Mathis A, Schmid N, Meli ML, HofmannLehmann R, Lutz H, Deplazes P, Ryser-Degiorgis MP. 2007. Babesiosis in free-ranging chamois (Rupicapra r. rupicapra) from Switzerland. Veterinary Parasitology, 148, 341-345.

18. Hoby S, Mathis A, Doherr MG, Robert N, Ryser-Degiorgis MP. 2009. Babesia capreoli infections in alpine chamois (Rupicapra r. rupicapra), roe deer (Capreolus c. capreolus) and red deer (Cervus elaphus) from Switzerland. Journal of Wildlife Diseases, 45, 748-753.

19. Heyman P, Cochez C, Hofhuis A, van der Giessen J, Sprong H, Porter S, Losson B, Saegerman C, Donoso-Mantke O, Niedrig M, Papa A. 2010. A clear and present danger: tick-borne diseases in Europe. Expert Review of Anti-infectious Therapy, 8, 33-50.

20. Jouda F, Perret J-L, Gern L. 2004. Density of questing Ixodes ricinus nymphs and adults infected by Borrelia burgdorferi sensu lato in Switzerland: spatio-temporal pattern at a regional scale. Vector-Borne and Zoonotic Diseases, 4, 23-32.

21. Kiewra D, Kryza M, Szymanowski M. 2014. Influence of selected meteorological variables on the questing activity of Ixodes ricinus ticks in Lower Silesia, SW Poland. Journal of Vector Ecology, 39, 138-145.

22. Kourkgy C, Garel M, Appolinaire J, Loison A, Toïgo C. 2016. Onset of autumn shapes the timing of birth in Pyrenean chamois more than onset of spring. Journal of Animal Ecology, 85, 581-590.

23. Lillini E, Macri G, Proietti G, Scarpulla M. 2006. New findings on anaplasmosis caused by infection with Anaplasma phagocytophilum. Annals of the New York Academy of Sciences, 1081, 360-370.

24. Liz JS, Sumner WJ, Pfister K, Brossard M. 2002. PCR detection and serological evidence of granulocytic ehrlichial infection in roe deer (Capreolus capreolus) and chamois (Rupicapra rupicapra). Journal of Clinical Microbiology, 40, 892-897.
25. Lommano E, Bertaiola L, Dupasquier C, Gern L. 2012. Infections and coinfections of questing Ixodes ricinus ticks by emerging zoonotic pathogens in Western Switzerland. Applied and Enivronmental Microbiology, 73, 4606-4612.

26. Mannelli A, Bertolotti L, Gern L, Gray J. 2012. Ecology of Borrelia burgdorferi sensu lato in Europe: transmission dynamics in multi-host systems, influence of molecular processes and effects of climate change. FEMS Microbiology Reviews, 36, 837-861.

27. Marconi RT, Garon CF. 1992. Development of polymerase chain reaction primer sets for diagnosis of Lyme disease and for specie-specific identification of Lyme disease isolates by $16 \mathrm{~S}$ rRNA signature nucleotide analysis. Journal of Clinical Microbiology, 30, 2830-2834.

28. Massung RF, Slater K, Owens JH, Nicholson WL, Mather TN, Solberg VB, Olson JG. 1998. Nested PCR assay for detection of Garnulocytic Ehrlichiae. Journal of Clinical Microbiology, 36, 1090-1095.

29. Michel A, Mathis A, Ryser-Degiorgis MP. 2014. Babesia spp. in European wild ruminant species: parasite diversity and risk factors for infection. Veterinary Research, 45, 65.

30. Oeschslin CP, Heutschi D, Lenz N, Tischhauser W, Peter O, Rais O, Beuret CM, Stephen Leib L, Bankoul S, AckermannGaumann R. 2017. Prevalence of tick-borne pathogens in questing Ixodes ricinus ticks in urban and suburban areas of Switzerland. Parasites \& Vectors, 558, 558.

31. Ortuno A, Castella J, Marco I, Ruiz M, Lavin S. 2003. Prevalence of antibodies to Borrelia burgdorferi sensu lato in southern chamois (Rupicapra pyrenaica) in Spain. Journal of Veterinary Medicine, 50, 253-254.

32. Ostfeld R, Brunner J. 2015. Climate change and Ixodes tickborne diseases of humans. Philosphical Transactions of the Royal Society B Biological Sciences, 370, 20140051.

33. Parola P, Raoult D. 2001. Ticks and tickborne bacterial diseases in humans: an emerging infectious threat. Clinical Infectious Diseases, 32, 897-928.

34. Parola P, Davoust B, Raoult D. 2005. Tick- and flea-borne rickettsial emerging zoonoses. Veterinary Research, 36, 469-492.

35. Parola P, Paddock C, Socolovschi C, Laruna M, Mediannikov O, Kernif T, Abdad MY, Stenos J, Bitam I, Fournier PE, Raoult D. 2013. Update on tick-borne rickettsioses around the world: a geographic approach. Clinical Microbiology Review, 26, 657-702.

36. Parola P, Roux V, Camicas J-L, Baradji I, Brouqui P, Raoult D. 2000. Detection of Ehrlichia in African ticks by polymerase chain reaction. Transactions of the Royal Society of Tropical Medicine and Hygiene, 94, 707-708.

37. Perez-Eid C. 2007. Les tiques - identification, biologie, importance medicale et vétérinaire. Paris: Lavoisier.

38. Pintore M, Ceballos L, Lulini B, Tomassone L, Pautasso A, Corbellini D, Rizzo F, Mandola ML, Bardelli M, Peletto S, Acutis PL, Mannelli A, Casalone C. 2015. Detection of invasive Borrelia burgdorferi strains in North-Eastern Piedmont, Italy. Zoonoses and Public Health, 62, 365-374.

39. Regnery R, Spruill C, Plikaytis B. 1991. Genotypic identification of rickettsiae and estimation of intraspecies sequence divergence for portions of two rickettsial genes. Journal of Bacteriology, 173, 1576-1589.

40. Reis C, Cote M, Paul R, Bonnet S. 2011. Questing ticks in suburban forest are infected by at least six tick-borne pathogens. Vector Borne and Zoonotic Diseases, 7, 907-916.

41. Richard Q. 2016. Hétérogénéité individuelle, variabilité temporelle et structure spatiale comme source de variation démographique chez les grand herbivores de montagne. $\mathrm{PhD}$ Thesis, Bourget du Lac, France: Université Savoie Mont Blanc. 
42. Richard Q, Toïgo C, Appolinaire J, Loison A, Garel M. 2017. From gestation to weaning: combining robust design and multi event models unveils cost of lactation in a large herbivore. Journal of Animal Ecology, 86, 1497-1509.

43. Schmid N, Deplazes P, Hoby S, Ryser-Degiorgis M-P, Edelhofer R, Mathis A. 2008. Babesia divergens-like organisms from free-ranging chamois (Rupicapra r. rupicapra) and roe deer (Capreolus c. capreolus) are distinct from B. divergens of cattle origin - an epidemiological and molecular genetic investigation. Veterinary Parasitology, 154, 14-20.

44. Stanczak J, Cieniuch S, Lass A, Biernat B, Racewicz M. 2015. Detection and quantification of Anaplasma phagocytophilum and Babesia spp. in Ixodes ricinus ticks from urban and rural environment, northern Poland, by real-time polymerase chain reaction. Experimental and Applied Acarology, 66, 63-81.
45. Stuen S, Granquist E, Silaghi C. 2013. Anaplasma phagocytophilum - a widespread multi-host pathogen with highly adaptive strategies. Frontier in Cellular and Infection Microbiology, 3, 31 .

46. Vandenesch A, Turbelin C, Couturier E, Arena C, Jaulhac B, Ferquel E, Choumet V, Saugeon C, Coffinieres E. 2014. Incidence and hospitalisation rates of Lyme borreliosis, France, 2004 to 2012. Eurosurveillance, 19, 34.

47. Wickel S. 2018. Ticks and tick-borne infections: complex ecology, agents, and host interactions. Veterinary Sciences, 5, 60.

48. Woldehiwet Z. 2010. The natural history of Anaplasma phagocytophilum. Veterinary Parasitology, 167, 108-122.

Cite this article as: Akl T, Bourgoin G, Souq M-L, Appolinaire J, Poirel M-L, Gibert P, Abi Rizk G, Garel M \& Zenner L. 2019. Detection of tick-borne pathogens in questing Ixodes ricinus in the French Pyrenees and first identification of Rickettsia monacensis in France. Parasite 26, 20.

\section{PARASTE}

An international open-access, peer-reviewed, online journal publishing high quality papers on all aspects of human and animal parasitology

Reviews, articles and short notes may be submitted. Fields include, but are not limited to: general, medical and veterinary parasitology; morphology, including ultrastructure; parasite systematics, including entomology, acarology, helminthology and protistology, and molecular analyses; molecular biology and biochemistry; immunology of parasitic diseases; host-parasite relationships; ecology and life history of parasites; epidemiology; therapeutics; new diagnostic tools.

All papers in Parasite are published in English. Manuscripts should have a broad interest and must not have been published or submitted elsewhere. No limit is imposed on the length of manuscripts.

Parasite (open-access) continues Parasite (print and online editions, 1994-2012) and Annales de Parasitologie Humaine et Comparée (1923-1993) and is the official journal of the Société Française de Parasitologie. 